\title{
Unilateralism in Refugee law-Austria's Quota Approach Under Scrutiny
}

\author{
Peter Hilpold ${ }^{1}$ (D)
}

Published online: 26 June 2017

(C) The Author(s) 2017. This article is an open access publication

\begin{abstract}
In the aftermath of the "Arab Spring" and of crumbling state structures, an exodus of unknown proportion from the Near East and from Northern Africa has set in and was further exacerbated by civil war and ISIS terror rule over large territories in the Near East. As a consequence, thousands of refugees came to Europe. Many of them fulfilled the conditions for non-refoulement according to Article 33 of the Geneva Convention on the Law of Refugees of 1951 or were at least entitled for temporary protection according to the Common European Asylum System. These instruments did not, however, take into consideration situations of mass influx and neither is there an efficient mechanism for burden sharing within the EU in place. Some countries where overwhelmed by these migration flows. In this contribution, particular attention will be given to the reactions to these developments by the Austrian government. In Austria, as a consequence of mounting pressure by considerable parts of the population demanding a halt to this migration, the government adopted or announced a series of measures that, if implemented, will constitute a blatant violation of international law. This holds true, in particular, for the so-called upper limit ("Obergrenze") for asylum seekers. Legal academia in Austria in part was silent as to these events, in part sustained it after having been engaged for a legal. It is contended here that unilateralism may be effective in a short-time perspective, but the long-term consequences should not be overlooked. It would be better to work on a genuine international burden-sharing mechanism even though this approach is more difficult to sell to national constituencies.
\end{abstract}

Keywords Refugee law $\cdot$ Asylum law $\cdot$ Austria $\cdot$ Quotas $\cdot$ State of necessity

Peter Hilpold

Peter.Hilpold@uibk.ac.at

1 University of Innsbruck, Innrain 52, 6020 Innsbruck, Austria 


\section{Introduction}

In the years 2015 and 2016, Austria has come under unprecedented pressure by an abrupt rise of migratory flows and a dramatic upsurge in asylum applications. While in 2014, 88,151 asylum applications were presented this number more than tripled in 2015 and the developments in the first months of 2016 warranted expectations of even higher numbers for that year. ${ }^{1}$

These events were part of a broader turmoil involving several states in Europe and the European Union (EU) as a whole, which faced, within 2 years, an inflow of over 1 million refugees and migrants (European Commission 2016, The EU and the Refugee crisis). Austria, as it is geographically set in the midst of the north-south and the east-west migratory routes in Europe, was one of the countries that had to bear the brunt of this crisis. This situation was further exacerbated by the fact that Austria offers a relatively high standard of living and grants generous social benefits to those in need.

The EU tried hard to find a common answer to this challenge. A series of highranking meetings by representatives of the union and Member States (MS) was dedicated to this question, and a lot of documents and papers were produced on this subject, devising in part pragmatic, in part high-flying, lofty problem solution strategies (European Commission 2015, European Agenda on Migration). On a whole, however, the results of these endeavours were disappointing and did not convey the impression that the union was really up to this task or could handle it in a somewhat satisfactory way. In part, this was a direct consequence of the sheer number of refugees the union had to deal with. In fact, according to the UNHCR Report 2015 (The UN refugee agency 2015), by the end of 2015, 63.5 million individuals were forcibly displaced worldwide. ${ }^{2}$ Surely, the Syrian crisis had generated a refugee problem that exceeded all proportions and had hit the union totally unexpectedly. At the same time, however, this crisis had laid bare problems that were also internal to the union as the EU had been caught totally by surprise by the phenomenon of mass migration as a whole and in the aftermath had proven to be widely inept to react efficiently to this challenge. Most fundamentally, this crisis had revealed that the much-vaunted concept of solidarity on which European integration rests to a large extent (on the concept of solidarity Boutayeb 2011) could hardly withstand a situation of extraordinary stress as represented by the migration crisis.

As will be shown, what followed was, in the essence, an attempt to find a short-term answer to the migration and asylum crisis. This happened primarily by unilateral measures, and in this context, Austria became a leading voice in Europe and seemed to show, for better or worse, the path to be taken, amid the applause by some other countries mostly affected by this crisis (especially on the Balkans) and the-much stronger - criticism by other countries, by NGOs, ${ }^{3}$ (Erzdiözese Wien 2016) human rights institutions (Schöffl 2016) and international lawyers (Golod 2016). At first

\footnotetext{
${ }^{1}$ Statistics according to the Austrian Ministry for Internal Affairs (Bundesministerium für Inneres 2017)

2 This number is up 5.8 million in relation to the previous year, and it is composed of 21.3 million refugees, 40.8 million internally displaced persons and 3.2 million asylum seekers. Ibid.

${ }^{3}$ For one of the many statements by the caritas on the Austrian refugee policy, see https://www.erzdioezesewien.at/site/home/nachrichten/article/48720.html. For criticism voiced by Human Rights Watch in April 2016: https://www.hrw.org/news/2016/04/27/austria-drastic-unjustified-measures-against-asylum-seekers.
} 
glance, this act might be seen as a denial of solidarity. At a closer look, however, this finding might be put into question. As will be seen, unilateralism could be seen as a first, probably inadvertent step to redefine solidarity, a contribution to capture its very essence and to transform it from a lofty petitio principii into an instrument capable to redistribute burdens and to give thereby an important contribution for the solution of the problem. At the same time, however, care must be taken, not to exceed with this approach, thereby putting into risk pivotal achievements in international human rights law. In many ways, the present attempts to solve the migratory crisis are, therefore, also attempts to rebalance interests within the European Union and to find an acceptable and "workable" definition of solidarity within this region. Of course, these attempts take place in a broader international setting, but this only signifies that the solutions looked for within the EU will potentially have relevance in a worldwide context. The meaning given to solidarity within the EU might reflect many traits that are unique for this region, but at the same time, it is contended here that the basic structural elements of solidarity apply on a worldwide scale. The present developments in EU migration and refugee law and the attempts to find a fair and effective solution to the related problems could influence to a considerable extent the way how a rights-based management of migratory flows is universally to be devised (or not to be devised). ${ }^{4}$ Lack of consent on how to conceive a universal system of burden sharing with regard to international migrants and asylum seekers led on all governance levels to unilateral problem solution attempts evidencing at the same time a serial multilateral governance failure. Unilateralism took many forms, such as the closure of borders, the erecting of barbed-wire fences, attempts to criminalize immigration, but one of the most popular ideas was the introduction of quotas. Again, this concept was not a uniform one but was presented in many variants and under the most different headings. Some of these approaches, such as that adopted by the EU, were portrayed primarily as an attempt to implement some form of burden sharing, thereby giving concrete meaning to solidarity. Others, such as the Austrian model, were presented first of all as a measure of necessity catering to the needs of the domestic population. Of course, the respective situations in part effectively differed as the EU had to take care of a situation where asylum seekers were scattered all over the union in a very uneven way, while the discussion about stricter border measures took place on a different level. In Austria, to the contrary, the quota was an immediate outflow of the attempt to regulate the inflow of refugees at the border. Nonetheless, it has also to be considered that part of this different focus in the presentation of the quota plans was due to the fact that the announcements were directed to a different audience with widely diverging expectations: The EU institutions had firstly to demonstrate to their MS that the union was able to create a fair balance between the burdens the single EU MS had to shoulder also as a consequence of the introduction of the Common European Asylum System (CEAS). Secondly, and in a more general sense, the EU institutions had to take care to evidence that this institution was able to give an effective meaning to solidarity, a principle formally so strongly upheld in EU law (see Neisser 2016).

Nonetheless, notwithstanding all these differences in the political and the practical background, it should not be overlooked that eventually, all forms of quota systems in the

\footnotetext{
${ }^{4}$ On the potential and the limits of an international migration management regime, see extensively Kotzur 2017 and Breitenmoser 2017.
} 
administration of refugee flows are based on very similar premises and lead to comparable results.

This contribution is aimed at analysing the Janus face of quotas in refugee law: They are clearly forbidden by the main refugee protection systems in international law, and in particular by the Geneva Convention on the law of refugees if they are seen as an instrument to administer the right to asylum at the border. This does not mean, however, that they would also be forbidden as an internal instrument for the administration of migration, or that they would be illegal in the absolute in the case protection which can be provided elsewhere. International refugee and migration law displays many gaps, and it could be argued that the instruments presently in force need to be supplemented by a specific burden-sharing instrument based, i.a., on the introduction of quotas for the case of a mass influx. If applied universally, the right to protection could in principle be upheld.

Of decisive importance will be how this instrument is effectively handled. For the time being, quotas operate widely in a grey area. They may exert a sustaining effect on the existing refugee protection measures, but they may also effectively undermine them. It is contended here that the attempts by the Austrian government started in early 2016 to introduce such a quota system that operates as an extraordinary showcase to evidence on the one hand the opportunities, and on the other hand, the limits and pitfalls this instrument offers. Any attempt to turn to unilateralism in order to enforce solidarity has to be handled with great care. As will be shown, a very demanding balancing of interests, a fine-tuning between different ambitions and goals that are in part conflicting, is required.

\section{Solidarity re-Interpreted}

The closure of borders and the introduction of unilateral measures we have been witnessing in the last years are often portrayed as a radical departure of the past and as the end of a golden era of solidarity. To a certain extent, this may be true but reality is nonetheless more complicated.

First of all, we have to sort out what solidarity in international relations really means. Often, this concept is associated with the idea of unilateral generosity, of altruism expecting no reward, pretending nothing in return. Such an understanding of solidarity appears to be ill guided and ingenuous as it is out of touch with human nature and social reality (Hilpold 2015a, b).

While altruism and unilateral benevolence surely have their firm place in human relations, it is hardly conceivable to try to solve larger international challenges on this basis, especially if for such efforts, sizeable resources are needed on a longer time range as this is the case with the refugee problem. As it has been said, "solidarity expects solidarity" (Isensee 1998). There is a strong do ut des element in thinking about solidarity, at the least in the form of an insurance mechanism that provides protection against incalculable risks for the single entity or the single person (Hilpold 2015a, b). And this element refers to the concept of reciprocity, probably the single most important idea able to explain why international law works without central state-like institutions (see Simma 1972). Of course, several distinctions are needed here as we have to take care not to put into question basic 
achievements of international law, in particular in the field of human rights law. At a closer look, the reasons why human rights protection works and, at the same time, why this protection only works to a limited extent may be very well explained taking recourse to the concepts developed above. ${ }^{5}$ And these considerations can very well be transposed to the refugee and migration issue. Human rights protection made great advances in times of extraordinary challenges that strengthened the sense of a common bond between all members of mankind. In these times, the spirit of altruism is very pronounced. In such a situation, a strong human rights protection system can also be seen as sort of an insurance system providing potential protection against vicissitudes that can hit anyone in the worldwide human society. This may explain the huge advances in international human rights protection after World War II and also the fact that it was possible to create a refugee protection system like the Geneva Convention on the Protection of Refugees (GCR) of 1951. In the years before, the flight problem had hit the European continent, already badly affected by the war, in a disruptive way. Preparedness to help was further strengthened by the fact that in many cases, there were strong ethnic, linguistic or cultural ties between refugees and people in the territories providing shelter. This held in particular true for the over 10 million refugees of German nationality that came to Western Germany. This was a one-time situation characterized by a spirit of solidarity that only situations of need of catastrophic dimension can create. ${ }^{6}$ In 1951 , when the GCR was adopted, the mass exodus from the east had already come down to a trickle. Now, no longer ethnically or ideologically motivated expulsion was the root cause of flight but rather political persecution in a closer sense that could be ideally tackled by a human rights instrument such as the GRC that centred on the individual.

Solidarity in the post-war period was additionally strengthened by a sense of guilt or co-responsibility for the plight of the refugees from the East. ${ }^{7}$

All these elements are missing in the present refugee and migration crisis. There is neither a broader sense of co-responsibility for the flight causes in the Near East and in Africa (as it was given, for example, after World War II, on a worldwide scale, or after

\footnotetext{
5 Traditionally, it has been said that the principle of reciprocity does not work in the field of human rights. See, for example, Provost 1994. R. Provost, Reciprocity in Human Rights and Humanitarian Law, in: 65 BYIL 1994, pp. 383-454. See also the statement by the European Commission according to which the purpose of the European Convention of Human Rights "was not to create reciprocal obligations and rights, but rather to establish a common public order." Case Austria/Italy, Appl. 788/60, 1961, Yb Eur. Conv. Hum. Rts. 116, 13840. On the basis of these propositions stands, however, an understanding of reciprocity that strictly applies only to inter-state relations. Here, a broader understanding of reciprocity is adopted that applies generally to human relations, both individually and collectively.

${ }^{6}$ Here, the concept of "vicinity", first introduced by the English philosopher Edmund Burke, shines through. By this concept, Burke wanted to describe the fact the proximity between two people increases the interest for each other's lot. See E. Burke, Letters on a Regicide Peace (Third Letter on a Regicide Peace, 1796), reprinted in The Works of the Right Hon. Edmund Burke, vol. II (London: Holdsworth and Ball, 1834).

7 This was also the reason why in Germany in 1952, a "Lastenausgleichsgesetz"(" burden-sharinginstrument") was adopted: Those who had lost their means as a consequence of the confiscation policy by communist countries should at least partially be compensated by means taken from people living in the secure Western German territories. At the same time, this internal rebalancing of burdens related at least indirectly to a compensation policy by which compensation for Germany's war responsibility was effectuated by the cession of territories. See Stahn 2007.
} 
the Vietnamese war with the US and some of its Western allies) nor is there a strong conviction that acceptance of greater numbers of refugees could alleviate the problem on a global level. The perception is rather that the destination countries of the refugee flows become over-burdened and over-strained while not only having no immediate benefit from this benevolence but even running the risk of laying the foundations for incalculable future challenges and burdens. The ensuing problems cannot be solved by recourse to the GCR. Absence of a parallel ad hoc burden-sharing mechanism, the GCR is simply not strong enough to bear the burden of the present day refugee challenge. Conversely, notwithstanding its age, this instrument is still very well suited to provide satisfactory solutions for individual refugee problems. In these cases, even reciprocity works as refugees fleeing from individual persecution provide additional strength and confirmation for the fundamental rights system in the destination countries.

The GRC, however, offers no basis for measures against a mass influx of refugee seekers. No excessive burden exception is permissible on the basis of the text of this convention. This aspect is so essential to this convention that not even the New York Protocol of 1967 by which the Eurocentric perspective was changed into a universalistic one brought about any change in this regard. Not that mass flight would have become a relic of the past, quite the contrary. Colonial and post-colonial war led to enormous movements of populations fleeing destruction and death, in particular in Africa. These events happened, however, outside Europe, and they touched Europe only marginally, if at all. Thus, in Europe, for long, the illusion could be upheld that the refugee problem could be continued to be tackled as an individualistic phenomenon. The Cold War, with the Iron Curtain sharply reducing the refugee flows, gave comfort to this view. The uniqueness of this instrument and its acceptance in particular in Europe could thereby be preserved. In the first years of its operation, as long as the GRC remained "European" in all senses, this limited ambition of the GRC had even as a consequence that this convention risked becoming a victim of its own success. In fact, the nearly unsurmountable borders of Western Europe raised the question whether it made much sense to maintain in force such a sophisticated instrument as the GRC. In UN Res. 1166 (XII) of 26 November 1957, even the abolition of this convention was envisaged, a plan fortunately not enacted (Roberts 1998).

All in all, these episodes reveal that the GRC is by far not the all-encompassing refugee protection instrument providing for any possible refugee problem and it has never been. It was rather the lack of alternatives and the solution of mass flight problems via ad hoc measures never largely publicized that created the false impression that this document would be nearly universal not only with regard to the number of signatories but also in relation to its problem solution ambition and power. This document was rather full of "constructive ambiguities" 8 that obfuscate its nature and goals.

The Cold War, rigid border controls and relatively stable governments in the neighbouring Mediterranean countries made sure that these deficits of the international refugee system did not come fully apparent. In the meantime, all this has changed and absence of an international instrument that could effectively stem the tide of international migration states - and also the European Union - take recourse to unilateral measures. In this regard, as already mentioned, the quota becomes a formidable instrument.

\footnotetext{
${ }^{8}$ On the origins of this concept, see Hilpold 2015b.
} 
With regard to the European Union, the quota has primarily become an instrument to rebalance the burden created by the uncontrolled influx of refugee seekers and other migrants between the single MS. ${ }^{9}$ As is well known, the most prominent expression to this attempt was given in a relocation plan of 22 September 2015 on the basis of which 120,000 refugees, presently primarily located in the so-called frontline states (Italy, Greece and Hungary), should be re-distributed between the various MS. As of March 2017, this plan is, however, still largely unimplemented (Hilpold 2017). ${ }^{10}$ This failure comes on top of the fact that anyway, this initiative, even in case of full success, would have provided only a very limited contribution for the solution as a whole. As a consequence, several MS took recourse to unilateral measures. The ones taken or announced by the Austrian government have gained particular prominence and shall be analysed in detail in the following.

\section{The Unilateral Introduction of Quotas}

In recent years, Austria has assumed sort of a leadership within the EU MS when it came to devise unilateral measures to confront the refugee problem. ${ }^{11}$ As is well known, after an unprecedented influx of asylum-seekers and growing resistance within the population

\footnotetext{
${ }^{9}$ See also the recent assessment of the deficits of the EU's CEAS by Guy S. Goodwin-Gill: "Europe's idealized and optimistic common asylum system, and its agenda for migration has failed to meet the challenge of recent years, whether it be the large numbers arriving in search of refuge or opportunity, or the need for more effective arrangements on migration matter with non-EU states. The challenges themselves have also revealed major deficits in the EU's organizing principles of solidarity, cooperation, and mutual support". See Goodwin-Gill 2016.

${ }^{10}$ The largely failed attempt by the European Union to introduce a quota system by which the refugee crisis should be handled is symptomatic for the deficiencies of the EU decision-making process as well as for the crisis of solidarity within the Union. The specific problem has been analysed elsewhere (Hilpold 2017) and shall be rehearsed here only in its main elements. A first attempt to adopt a quota mechanism was started by the EU Commission in May 2015. According to this plan, 40,000 refugees stranded in Italy and Greece (Syrian and Eritrean nationals) should be resettled to other Member States (MS), while another 20,000 persons in clear need of international protection should be permitted entrance into the EU. This proposal was adopted by the EU Council on 14 September 2014, but soon it became clear that more had to be done, and so on 9 September 2015, the commission presented a second package of measures according to which 120,000 people should be relocated from frontline states (Italy, Greece and Hungary) and distributed to other MS according to a sophisticated key-based i.a. on the size of the population of the receiving MS and their GDP. The commission proposed also a permanent relocation mechanism to be triggered by the commission in crisis situations. All these measures are based on the solidarity mechanism according to Article 78 para. 3 TFEU. In practice, however, this relocation mechanism met with strong resistance by several states. The second package was adopted by the EU interior ministers on 22 September 2015 with the Czech Republic, Hungary, Romania and Slovakia voting against, while Finland abstained. Other MS which first voted in favour of this package afterwards showed passive resistance in the implementation process. In March 2017, the Austrian government declared that it wanted to be exempted from further relocation measures as the previous measures taken by Austria should be taken into consideration. The EU Commission, however, insisted that Austria should fulfil obligations from the relocation programme (Die Presse 2017).

${ }^{11}$ In this regard, the measures taken by the Swedish government in 2015 may have constituted, to a certain extent, a precedent. In fact, while Sweden in the past has been a very open country admitting a relatively high share of the asylum seekers coming to Europe, growing opposition within the population against this policy has prompted the government to change its policy in this regard. It introduced immigration restrictions based on emergency measures sustaining that the immigration had put high stress on state functions such as housing, health care and hospitals and social services. Starting from this assessment, the government deduced "that the current situation in a wide perspective constitutes a serious threat against public order and internal security". Lag 2015, 1073, cited according to Klamberg, Reconstructing the Notion of State of Emergency under Human Rights Law 2016.
} 
against this development, the Austrian government has taken the initiative for a broader revision of the Austrian asylum law enshrined in a law of 2005 (Asylgesetz 2005-AsylG 2005). Centre stage of these reform attempts is the introduction of an "upper limit" of 37,500 asylum seekers that would be accepted in Austria. According to the government, such a measure would be in conformity with international and European law, ${ }^{12}$ a claim that is obviously unsustainable. ${ }^{13}$

According to the amendment to the asylum law of 2005 approved on 27 April 2016, ${ }^{14}$ the competent administrative bodies should be allowed to carry out summary asylum procedures, and furthermore, the basis was laid for the introduction of an upper limit of 37,500 asylum seekers to be admitted annually if the public order or the internal security was endangered. This limit has not been inserted in the asylum law as such, but governmental representatives have left no doubt as to the circumstance that the government will stick to this "Obergrenze" as soon as the relevant para. Thirty-six of the asylum law as amended in April 2016 will be implemented by an emergency decree. As to the circumstances that will trigger the emanation of the emergency decree, the explanatory report to the governmental draft of the amendment law refers i.a. to strains on the labour market, insufficient housing for asylum seekers, extraordinary burdens for the asylum authorities and the need to preserve public order and security (Austrian Parliament 2016).

As already mentioned on an international plane, it appears to be absolutely unprecedented - perhaps with the only exception of the Swedish case of $2015^{15}$ - if Austria should rely simply on an "infringement" of the functionability of national institutions in order to suspend its obligations from the GCR or the CEAS.

As demonstrated, within the GCR, a mass influx of refugees does not give rise to any exception from the convention obligations by reference to "public security" or "internal order". This has direct effects with regard to EU asylum law: In consideration of the fact that the CEAS primarily builds upon the GCR, ${ }^{16}$ it seems hardly probable that such an exceptional rule could form out in the EU area. It could be contended that the CEAS has gone beyond the GCR creating more extensive exceptional rules, but at a closer look also, this assumption fails to convince. Although there is only sparse literature on this subject, there can be no doubt that also in EU law, these exceptions have to be interpreted restrictively. In fact, as the ECJ has stated, "the concept of public policy presupposes, in any event, the existence, in addition to the perturbation of the social order which any infringement of the law involves, of a genuine, present and sufficiently serious threat affecting one of the fundamental interests of society". ${ }^{17}$ As has been demonstrated in detail, 18 the Austrian government has not provided any convincing evidence for the existence of such a threat.

\footnotetext{
${ }^{12}$ This claim is based on an opinion commissioned by the Austrian government after the decision to introduce such an "upper limit" had already been taken on the political level. In order to soothe somewhat the tone of the discussion, some political representatives tried to qualify this upper limit ("Obergrenze") as an indicative value ("Richtwert"), but at the same time, it was also - repeatedly - made clear that the government intended to stick to this value so that the first expression seems to give better expression to the actual political will. 13

${ }^{14} \mathrm{GBl}$ I Nr 100/2005 idF BGBl I no. 24/2016.

${ }^{15}$ See note 63 .

${ }^{16}$ See Article 78 TFEU.

${ }^{17}$ See ECJ, C-434/10, Aladzhov, para. 35; EuGH, C-33/07, Jipa, para. 23, cited according to Benedek, Salomon 2016.

${ }^{18}$ Ibid., p. 4.
} 
As to the material and procedural restrictions, the examination of the asylum requests should be subjected to the government that seeks justification by reference to purported far-reaching exceptions in asylum and refuge law ${ }^{19}$ - thereby, however, ignoring the relevant literature which is fairly extensive in particular in the field of public international law. The same deficiency can be identified in the Opinion commissioned by the government (Funk and Obwexer 2016) on which the explanatory report to the governmental draft widely draws. Furthermore, this Opinion is based on a-mistaken - neat distinction between asylum law and nonrefoulement obligation, ${ }^{20}$ a distinction that can hardly be derived from existing international law. In fact, since long, the dynamic development of the GCR has brought about a broad commixtion of these concepts which retain their autonomy only under specific considerations. ${ }^{21}$

As to the EU law, it is difficult to understand how one can negate the existence of a right to asylum within the context of the $\mathrm{CEAS}^{22}$ and to restrict accordingly Article 18 of the European Charter of Fundamental Rights. ${ }^{23}$

${ }^{19}$ See the Explanatory Report to the "Gesamtändernden Abänderungsantrag zum Asylgesetz 2005".
https://www.parlament.gv.at/PAKT/VHG/XXV/AUA/AUA_00004/imfname_525278.pdf. 14ss. Accessed
4 March 2017.
${ }^{20}$ Ibid., pp. $47 \mathrm{~s}$.
${ }^{21}$ See Kugelmann 2010 para. p. 13: "[...] the scope of asylum in relation to refugee protection cannot
be easily determined". In fact, in academic literature, no longer a clear distinction between these
concepts can be found. Generally, it is said that asylum aims at comprehensive integration in the
asylum state while non-refoulement is only of a temporary nature. As is well known, the most
important international law instrument in the field of refugee protection, the GCR, contains only a
non-refoulment obligation. On the other hand, however, Article 34 of the GCR contains the provision
that "Contracting States shall as far as possible facilitate the assimilation and naturalization of
refugees". Furthermore, when the GCR was adopted, a recommendation (recommendation D) was
issued according to which government should "continue to receive refugees in their territories and that
they [should] act in concert in true spirit of international cooperation in order that these refugees may find asylum and the possibility of resettlement." See Gil-Bazo 2015.

${ }^{22}$ An Austrian newspaper reported a purported statement by one of the authors of the Opinion mentioned above: "EU lawyer Walter Obwexer cannot comprehend the reproaches by the EU Commission against the Austrian refugee measures made on Thursday. According to him this criticism is more or less pointless. In fact, the contention by the EU Commission that Austria has to accept asylum requests on the basis of the European Convention of Human Rights, the Charter of Fundamental Rights and the Geneva Convention, is false. These provisions do not grant a right to asylum but only the right not to be refouled to an unsafe country. As this is not the case for Slovenia no violation of the said provisions is given." (Translation by this author).

See http://diepresse.com/home/politik/innenpolitik/4928770/Faymann_Dass-wir-aufschreien-ist-unserePflicht?from=suche.intern.portal. Accessed 4 March 2017.

${ }^{23}$ See Benedek and Salomon 2016. According to Obwexer, it is not to be ruled out that the CEAS would permit the detention of refugees in a camp and to let them wait there for up to 2 years until their asylum request is processed. See http://www.zeit.de/politik/ausland/2016-01/oesterreich-fluechtlinge-obergrenze-walterobwexer/seite-2. Accessed 4 March 2017.

'The pertinent norms of the CEAS say, however, something different. See Article 20 para. 1 of EU Reg. 604/2013 (Dublin-III Reg.) and Article 6 of the Asylum Procedures Directive (Directive 2013/13/ EU) which do not permit exceptions even in situations of extreme necessity (for not to speak of cases of simple capacity management). Also, the ECJ has called for the unconditional respect for procedural guarantees. See C- 277/11 of 22. 11. 2012, M M vs. Minister of Justice, Equality and Law Reform, Ireland. 
The explanatory report mentioned above refers further to the "strain" exercised by the mass influx of refugees "on the whole asylum system and on primary care" 24 as well as to an "unprecedented tension for all public institutions in order to uphold a system of proper admission and integration procedures for foreigners", ${ }^{25}$ to the lack of "adequate and appropriate housing", ${ }^{26}$ to "destitute people compelled to earn their living on the street, thereby challenging the ordinate communal life in the receiving society", ${ }^{27}$ to the circumstance that "particularly rightist groups would exploit these challenges to stoke fears among the people" ${ }^{28}$ as well as to the "problem that a continuing high influx would put enormous stress on the budget. ${ }^{29}$

However, pleas of this kind could be presented by all of the MS that are most affected by the refugee problem. In part, these pleas are of a strong subjective nature, in part, they are speculative. Should they find recognition, this would de facto imply extensive derogations from the GCR and the CEAS. As a consequence, it would be more or less at the discretion of the single MS whether they wanted to implement the obligations stemming from these conventions or not.

It is likewise misleading to state, as the explanatory report does, ${ }^{30}$ that it has been the European Commission itself to prepare the ground for such a contention when, in a Commission Opinion of 23.10.2015 on the necessity and proportionality of the controls at internal borders reintroduced by Germany and Austria ${ }^{31}$ it generally justified emergency measures by reference to the ordre public argument (also Benedek and Salomon 2016). By so arguing, the Dublin regime and Schengen regime are conflated in an inadmissible way. Whether the public order is endangered has to be examined distinctively in the context of each legal regime and in relation to the measures that have to be adopted as a consequence. Therefore, the finding by the Commission that a sufficiently strong threat to the order public is given in order to justify the reintroduction of border controls (Schengen regime) does not imply a parallel statement as to the permissibility of restrictions in regard to the asylum provisions (Dublin regime). If at all, the considerations by the Commission point to the opposite direction as they emphasize both the importance of the principle of proportionality, and the fact that individual rights had not been infringed. Had a restriction of the asylum law been at question, these considerations would most probably have brought a different result. Article 23 of the Schengen Borders $\operatorname{Code}^{32}$ states that "where there is a serious threat to

\footnotetext{
${ }^{24}$ See Erläuterungen zum Gesamtändernden Abänderungsantrag zum Asylgesetz 2005, 18; https:/www. parlament.gv.at/PAKT/VHG/XXV/AUA/AUA_00004/imfname_525278.pdf.

${ }^{25}$ See Erläuterungen zum Gesamtändernden Abänderungsantrag zum Asylgesetz 2005, 19; https://www. parlament.gv.at/PAKT/VHG/XXV/AUA/AUA_00004/imfname_525278.pdf.

${ }^{26}$ See Erläuterungen zum Gesamtändernden Abänderungsantrag zum Asylgesetz 2005, 21; https://www. parlament.gv.at/PAKT/VHG/XXV/AUA/AUA_00004/imfname_525278.pdf.

${ }^{27}$ See Erläuterungen zum Gesamtändernden Abänderungsantrag zum Asylgesetz 2005, 22; https://www. parlament.gv.at/PAKT/VHG/XXV/AUA/AUA_00004/imfname_525278.pdf.

${ }^{28}$ See Erläuterungen zum Gesamtändernden Abänderungsantrag zum Asylgesetz 2005, 25; https://www. parlament.gv.at/PAKT/VHG/XXV/AUA/AUA_00004/imfname_525278.pdf.

${ }^{29}$ See Erläuterungen zum Gesamtändernden Abänderungsantrag zum Asylgesetz 2005, 26; https://www. parlament.gv.at/PAKT/VHG/XXV/AUA/AUA_00004/imfname_525278.pdf.

${ }^{30}$ See the Explanatory Report to the amendment proposal to the asylum law 2005, 18; https://www.parlament. gv.at/PAKT/VHG/XXV/AUA/AUA_00004/imfname_525278.pdf.

${ }^{31} \mathrm{COM}(2015) 7100$ final, 23 October 2015.

${ }^{32}$ Reg. (EC) No. 562/2006 of 15. 3. 2006 establishing a Community Code on the rules governing the movement of persons across borders (Schengen Borders Code).
} 
public policy or internal security, a Member State may exceptionally reintroduce border control at its internal borders for a limited period of no more than 30 days or for the foreseeable duration of the serious threat if its duration exceeds the period of 30 days". The asylum law knows no similar provision. The commixtion of different normative settings constitutes most probably the major problem both for the "Explanatory Report" as for the mentioned Opinion. Both the Opinion and the Explanatory Report (the latter being based on the former) refer to Article 72 TFEU which generally affirms that the provisions of title V on Justice and Home Affairs "shall not affect the exercise of the responsibilities incumbent upon Member States with regard to the maintenance of law and order and the safeguarding of internal security" in order to justify emergency measures in cases of a mass influx of refugees. The authors of these documents thereby overlook, however, that Article 78 para. 3 TFEU specifically provides for this case by introducing a competence by the Council to adopt provisional measures if one or more Member States are confronted with an emergency situation characterised by a sudden inflow of nationals of third countries. This provision is to be seen as a lex specialis in relation to Article 72 TFEU (see also Lansky 2016) where this latter norm is arguably merely intended to give political guidance to the EU legislator as to the necessity to respect pivotal security interests of the MS when touching upon this extremely delicate subject (Thym 2016).

Furthermore, also the infringement of the procedural guarantees for asylum seekers resulting from the amendment to the Austrian asylum law must raise worries. In particular, the delegation of expedited examination powers to police forces with no special knowledge in asylum law and leading to decisions that are immediately executory violates international law. ${ }^{33}$

As a result, it can be stated that if the latest amendment to the asylum law has laid the basis for the introduction of an upper limit for asylum applications and of restrictions as to the procedural guarantees for asylum seekers, international law or EU law does not provide any foundation for such a policy. It is true that the harshness of an upper limit shall be somewhat softened by the fact that the prohibition of torture (Article $3 \mathrm{ECHR} /$ Article 4 ECFR), the right to respect for private and family rights (Article $8 \mathrm{ECHR} /$ Article 7 ECFR) as well as the right to effective judicial remedy (Article 13 ECHR/ Article 47 ECFR) remain unconditionally guaranteed. ${ }^{34}$ Nonetheless, as shown, there remain broad areas of conflict with international norms. Attempts to sell the upper limit as a mere "indicative value" 35 are ultimately unconvincing as they go along with affirmations that the Austrian government must have the right to limit numerically the

\footnotetext{
33 This has been clearly stated by the UNHCR in a first analysis of the amendment law (UNHCR Kurzanalyse zum Gesamtändernden Abänderungsantrag 2016). Of course, returned asylum seekers can fight the rejection of their demand for asylum once returned to their country of origin. Obviously, this is highly impracticable and most often ends up in a denial of justice. In its analysis, the UNHCR clearly points out that the ECHR already in the past has stated that the examination of alleged violations of the non-refoulement obligation merely by police forces does not constitute an effective remedy according to Article 13 European Convention of Human Rights (citing Mohammed v. Austria, Application No 2283/12).

34 See Funk and Obwexer (2016), 44ff as well as 50.

In the Explanatory Report to the amendment law (https://www.parlament.gv. at/PAKT/VHG/XXV/AUA/AUA_00004/imfname_525278.pdf) an apodictic claim that "all primary, international and constitutional norms are respected" can be found. Ibid., p. 16.

35 See the Opinion cited in note 91, p. 51.
} 
influx of people from third states as well as stateless people. ${ }^{36}$ And even more fundamentally, it is to be underscored that Article 72 TFEU offers no valid basis for exceptional measures justified by reference to a threat to the public order or to internal security in cases of a mass influx of refugees.

\section{Conclusions and a Look Ahead}

As a result of these unilateral measures, we are now confronted with a deeply worrying, disturbing situation.

As has been shown, attempts to demonstrate the conformity of these measures with International Law and EU law have to be considered as failed. As far as the Explanatory Report to the amendment to the Austrian asylum law tries at all to argue legally, these arguments do not withstand closer scrutiny. But at the same time, the following phenomenon can be noticed: The unilateral measures taken by some MS, as objectionable they may be from a legal viewpoint, have factually reduced the "mixed migration flows" 37 towards Europe as a whole ${ }^{38}$ : both that of asylum seekers that would fall under the asylum norm of the GCR or of the CEAS as well as that of other immigrants, in particular that of economic immigrants. As a consequence, we are confronted with the following legal — and in particular, human rights - quandary: Within the broader population in many EU MS surely a limit as to the willingness to accept further immigration, be it of humanitarian or economic nature, has been reached (Köck 2016).

At the same time, however, the criteria set by international law or EU law for the adoption of emergency measures have not been reached. A recent study undertaken by the European Union Agency for Fundamental Rights shows that local communities might be seriously affected by larger inflows of refugees. ${ }^{39}$ In order to limit this impact, a series of measures by central and local authorities are suggested, measures that up to this moment often have not been taken. It would therefore be wrong to attribute the growing resistance to immigration to primordial xenophobia or to a deplorable lack of solidarity. Governments have to take into consideration the diffuse - and continuously growing - resistance among their national constituency against further immigration in a dimension as experienced in the last years. To this end, they have at their disposal a series of measures and instruments, none of which of easy application and none provided with anything like a guarantee for success.

The first best solution would be, of course, to create a separate instrument for tackling the problem of mass influx on an international level. ${ }^{40}$ This approach is, at

\footnotetext{
36 Ibid., p. 50.

${ }^{37}$ As to the concept of "mixed migration flows" see International Organization for Migration, Addressing Mixed Migration Flows, https:/www.iom.int/jahia/webdav/shared/shared/mainsite/about_iom/en/council/96 /Mixed Migration Flows FINAL.pdf.

${ }^{38}$ In this context, of considerable importance was the factual closure of the so-called "Balkan route".

${ }^{39}$ European Union agency for fundamental rights (2016) Thematic focus: Impact of the asylum crisis on local communities. http://fra.europa.eu/en/theme/asylum-migration-borders/overviews/local-communities. Accessed 4 March 2017.

${ }^{40}$ It could be contended that the EU already disposes of such an instrument: The temporary protection directive (Reg. 2001/55/EU), providing exactly for situations of mass influx. However, as is well known, this directive has not been implemented as of yet due to fears that such a mechanism could favour further immigration. It has become clear that an instrument is needed that involves further stakeholders and not only the European Union.
} 
the same time, the most arduous one as internationally little preparedness is perceptible to join the EU along this road. Nonetheless, this remains the most important long-term option. It will be associated with the creation of a worldwide burden-sharing system and could well bring along a universal quota system. ${ }^{41}$

Governments have chosen to go an easier way, in part because they do not own the resources for such complex negotiations, in part because they have to deliver short-term solutions to their constituencies which are becoming more and more impatient. This way consisted, as demonstrated with regard to the Austrian case, mainly in taking unilateral measures. Again, two different options were open for this government. It could have presented this approach as what as it was: As an open challenge to the present international refugee system out of the necessity to react to its deficiencies. Of course, such an attitude could have engendered international criticism as an open admission of a violation of international law, but, on the other hand, it is hard to see the government in the position to "throw the first stone". As shown, the governments acting unilaterally have chosen the safer way by downplaying or outright denying any violation of international law. This approach may have saved some political capital but at the same time, it cannot be overlooked that the overall consequences of this attitude are in many ways devastating.

First of all, transparency and, as a consequence, legal security are thereby greatly compromised. The impression is created that large parts of the international refugee system are more of a political than as of a legal nature ${ }^{42}$ (Brandstetter 2016). If such a perspective should gain hold, this could have devastating effects not only on the human rights culture but for international law in general. If international law rules cannot only be unilaterally interpreted at will but even be unilaterally derogated, a downward spiral may be opened up leading to an offset of pivotal legal achievements. ${ }^{43}$

At the same time, also academia is to blame when it, in part, supported this political U-turn with untenable arguments or was, in this discussion, conspicuous by its absence. ${ }^{44}$ Admittedly, it may not be easy for academics to stick firmly to legal achievements if the government - and broad parts of the population - are holding a strong view exactly to the contrary, but in the end, it is this autonomy that gives relevance to the voices of international lawyers.

As already anticipated in the introductory part, there is no simple reading of unilateral measures by national governments. They could be seen as an ultima ratio response to an overwhelming challenge also caused by the deficiencies of the international refugee

\footnotetext{
${ }^{41}$ In this direction, go proposals developed by James Hathaway already many years ago and further refined recently. See only http://www.irinnews.org/analysis/2016/05/09/time-reform-way-we-protect-refugees. Accessed 4 March 2017.

${ }^{42}$ In a letter to the EU Commissioner Dimitris Avramopoulos of 22 February 2016, the Austrian Federal Minister of Justice, Wolfgang Brandstetter, rejecting EU criticism against the Austrian projects for the introduction of an upper limit reminded the commissioner of the "relative nature of international law". He repeated this statement in an interview of 12 March 2016 with the national radio station Ö1.

${ }^{43}$ Currently, attempts are underway in Austria to stem illegal immigration by an increased recourse to criminal law measures and by the immediate withdrawal of food and shelter for asylum seekers whose applications are rejected. See

http://derstandard.at/2000049694541/Fremdenrechtspaket-bringt-Verschaerfungen-fuer-Asylwerber and http:/www.katholisch.at/aktuelles/2017/02/28/caritas-warnt-vor-zusaetzlicher-obdachlosigkeit.

Furthermore, asylum applicants who lie about their identities face a $€ 5000$ fine or 3 weeks in jail. See http://www.politico.eu/article/austria-plans-to-stop-giving-food-and-shelter-to-rejected-asylum-seekers/.

${ }^{44}$ It was disappointing to see that in Austria, contrary to the situation in Germany, the positions voiced by the international law academia were very sparse.
} 
system. In the meantime, however, two seemingly conflicting goals have to be realized: First of all, it is high time for a reset, for a return to legality. At the same time, however, governments (in Europe together with the Europe Union) have to retake control of international migration in response to a clear will expressed by large parts of the population. ${ }^{45}$ In order to reconcile these two goals, there will be no other choice than to openly admit that the existing international refugee and migration law is largely deficient and urgently needs strengthening by additional measures for mass migration phenomena, as they take place these days and by the introduction of a working burdensharing mechanism. It is time to stop the further weakening of International refugee and migration by unilateral measures and to return to multilateralism. ${ }^{46}$

Acknowledgements Open access funding provided by University of Innsbruck and Medical University of Innsbruck.

Open Access This article is distributed under the terms of the Creative Commons Attribution 4.0 International License (http://creativecommons.org/licenses/by/4.0/), which permits unrestricted use, distribution, and reproduction in any medium, provided you give appropriate credit to the original author(s) and the source, provide a link to the Creative Commons license, and indicate if changes were made.

\section{References}

Austrian Parlament (2005) Explanatory Report to the "Gesamtändernden Abänderungsantrag zum Asylgesetz 2005". https://www.parlament.gv.at/PAKT/VHG/XXV/AUA/AUA_00004/imfname_525278.pdf. 14ss. Accessed 30.3.2017.

Austrian Parliament (2016) Recht auf Asylverfahren kann künftig zeitweilig eingeschränkt werden. https://www.parlament.gv.at/PAKT/PR/JAHR_2016/PK0411/. Accessed 30 March 2017

Benedek W, Salomon St (2016) Stellungnahme zum Bundesgesetz betreffend Änderung des AsylG 2005, FÜPG 2005 und BFA-Verfahrensgesetz 2005. p. 3.

Biondi P (2016) Human security and external burden-sharing: the European approach to refugee protection between past and present. The International Journal of Human Rights 20(2): 208-222.

Boutayeb C (2011) La solidarité, un principe immanent au droit de l'Union européenne. In: Boutayeb C (ed) La solidarité dans l'Union Européenne, 5-37.

Brandstetter W (2016) Letter to the EU Comissioner for Migration, Home Affairs and Citizenship Dimitris Avramopoulos. https://kurier.at/politik/inland/justizminister-brandstetter-reagiert-auf-eu-ruege-zurobergrenze/182.555.733. Accessed 30.3.2017.

Breitenmoser St (2017) Migrationssteuerung im Mehrebenensystem. VVDStRL 76 (tob e published).

Bundesministerium für Inneres (2017) Statistik 2017 Asylwesen. www.bmi.gv.at. Accessed 19 February 2017.

\footnotetext{
$\overline{45}$ In literature, much criticism has been voiced against the general tendency to "re-nationalize" immigration policy (Biondi 2016; Hidalgo 2016). It is true that this tendency is worrying as it represents a serious step back in international refugee law. A strengthening of the international migration management regime would in any case be preferable. At the same time, however, care must be taken that host countries are not overburdened. In other words, it would be a mistake to assume that an international migration that fosters migration and immigration, in particular, in European countries has any chance to find acceptance. A new international migration regime is sorely needed, but it should be based on true international burden sharing, and it should emphasize problem solution mechanisms that address the very reasons for flight and poverty migration in the first place.

${ }^{46}$ This purpose could be met if serious attempts were undertaken to implement the New York Declaration on Refugees and Migrants of 19 September 2016 which, i.a., proposes also a "Global Compact on Refugees" that should specify international solidarity obligations and implement a comprehensive burden-sharing programme.

See Garlick and Türk (2016) who propose also an additional Protocol to the 1951 Convention to address large-scale refugee situations (ibid., p. 673).

On the lack of multilateral cooperation as a decisive hindrance for the solution of the present migration problem, see Hailbronner and Thym 2016 and Goodwin-Gill 2016.
} 
Die Presse (2017) Flüchtlinge: Kern und Juncker telefonierten wegen Umverteilung, Vienna 30 March 2017. http://diepresse.com/home/innenpolitik/5191646/Fluechtlinge_Kern-und-Juncker-telefonierten-wegenUmverteilung (Accessed 23.05.2017).

Erzdiözese Wien (2016) Asyl-Obergrenze Caritas warnt vor "Domino-Effekt”. https://www.erzdioezese-wien. at/site/home/nachrichten/article/48720.html. Accessed 30.3.2017.

European Commission (2015) European Agenda on Migration COM 214 final, 13 May 2015, the Council decisions on the introduction of a new solidarity mechanism. Council Decision 2015/1523 of 14 September 2015, O.J. 2015, L 239/146 and Council Decision 2015/1601 of 22 September 2015, O.J. 2015, L 248/80 and European Commission.

European Commission (2016) The EU and the refugee crisis. http://publications.europa. eu/webpub/com/factsheets/refugee-crisis/en/. Accessed 30.3.2017.

Funk B, Obwexer W (2016) Gutachten - Völker-, unions- und verfassungsrechtliche Rahmenbedingungen für den beim Asylgipfel am 20. 1. 2016 in Aussicht genommenen Richtwert für Flüchtlinge. Innsbruck/Wien.

Garlick M, Türk V (2016) From Burdens and Responsibilities to Opportunities: The Comprehensive Refugee Response Framework and a Global Compact on Refugees. International Journal of Refugee Law. 28 (4): 656-678.

Gil-Bazo M-T (2015) Asylum as a General Principle of International Law. International Journal of Refugee Law. 27 (1): 3-28.

Golod V (2016) Flüchtlings-Obergrenze schwer vereinbar mit EU-Recht. EuGH-Präsident. http://www.rponline.de/politik/eu/koen-lenaerts-obergrenze-bei-fluechtlingen-schwer-vereinbar-mit-eu-recht-aid1.5699465. Accessed 30.3.2017.

Goodwin-Gill G (2016) The Movements of People between States in the 21th Century: An Agenda for Urgent Institutional Change. International Journal of Refugee Law. 28 (4): 679-694.

Hailbronner K, Thym, D (2016) Grenzenloses Asylrecht? Die Flüchtlingskrise als Problem europäische Rechtsintegration. Juristenzeitung. 71 (15/16): 753-763.

Hidalgo J (2016) The case for the international governance of immigration. International Theory. 8(1): 140-170.

Hilpold P (2015a) Understanding Solidarity within EU Law: An Analysis of the 'Islands of Solidarity' with Particular Regard to Monetary Union. Yearbook of European Law. 34: 257-285

Hilpold P (2015b) The fight against terrorism and SC Resolution 2249 (2015): towards a more Hobbesian or a more Kantian International Society? Indian Journal of International Law. 55 (4): 535-555.

Hilpold P (2017) Quotas as an Instrument of Burden-Sharing in International Refugee Law - The Many Facets of an Instrument still in the Making. International Journal of Constitutional Law. 15 (forthcoming).

Isensee J (1998) Solidarität—sozialethische Substanz eines Blankettbegriffs. In Isensee J. Solidarität in Knappheit: Zum Problem der Priorität. Duncker \& Humblot. Berlin, 97-141.

Klamberg M. (2016) Reconstructing the Notion of State of Emergency under Human Rights Law. In http://papers.ssrn.com/sol3/papers.cfm?abstract_id=2812635. Accessed 30.3.2017.

Köck H F (2016) Internationale und europäische Aspekte des gegenwärtigen Flüchtlings- und Migrationsproblems. ZfRV 4: 148-154.

Kotzur M (2017) Migrationsbewegungen als Herausforderung für das Völkerrecht. BDGIR (to be published).

Kugelmann D (2010) Refugees. In MPEPIL online,13.

Lansky D (2016) Dodging a Bullet? Austrias Asylum Policy and the TFEU. In: Polemics. https:/dapolemics. com/2016/07/03/dodging-a-bullet-austrias-asylum-policy-and-the-tfeu/. Accessed 30.3.2017.

Neisser H (2016) Die Europäische Union zwischen Zweifel und Hoffnung. In Weiss A Ein anderes Europa: konkrete Utopien und gesellschaftliche Praxen. Verlag des Österreichischen Gewerkschaftsbundes. Vienna, 39-52.

Provost, R (1994) Reciprocity in Human Rights and Humanitarian Law. BYIL 65: 383-454.

Roberts A (1998) More Refugees, Less Asylum: A Regime in Transformation. In 11 Journal of Refugee Studies. 11: 540-542, referring to Von Mangoldt, Rittberger V (eds.) (1997) The United Nations System and its Predecessors, vol. I. The United Nations System. Oxford University Press: Oxford, 540-542.

Schöffl R (2016) UNHCR warnt vor Aushöhlung des Flüchtlingsschutzes. UN-Flüchtlingsorganisation erneuert Bedenken an geplanten Sonderverordnungen. http://www.ots.at/presseaussendung/OTS_20160907_ OTS0030/unhcr-warnt-vor-aushoehlung-des-fluechtlingsschutzes. Accessed 30.3.2017.

Simma B (1972) Das Reziprozitätselement im Zustandekommen völkerrechtlicher Verträge.

Stahn C (2007) Jus Post Bellum: Mapping the Discipline(s). 23 American University International Law Review. 23 (2): 311-347.

The UN refugee agency (2015) Global trends forced displacement. United nations high commissioner for refugees. http://www.unhcr.org/statistics/unhcrstats/576408cd7/unhcr-global-trends-2015.html. Accessed 30.3.2017.

Thym D (2016) In Hailbronner K, Thym D EU Immigration and Asylum Law, 45.

UNHCR (2016) Kurzanalysezum Gesamtänderenden Abänderungsantrag. http://www.unher. at/fileadmin/rechtsinfos/fluechtlingsrecht/4_oesterreich/4_2_asyl_positionen/4_2_4_positionen_ab_2011 /FR_AUS_Positionen_AsylG-Novelle_2016.pdf. Accessed 30.3.2017. 